\title{
Black Carbon Contributes Substantially to Allochthonous Carbon Storage in Deltaic Vegetated Coastal Habitats
}

\author{
Yuan Li, ${ }^{\nabla}$ Chuancheng Fu, ${ }^{\nabla}$ Lin Zeng, Qian Zhou, Haibo Zhang, Chen Tu, Lianzhen Li, \\ and Yongming Luo*
}

Cite This: Environ. Sci. Technol. 2021, 55, 6495-6504

Read Online

ACCESS | Lill Metrics \& More | 国 Article Recommendations ｜ st Supporting Information

ABSTRACT: Vegetated coastal habitats (VCHs) rank among the most intense carbon sinks in natural ecosystems, playing an important role in the global carbon cycle. A significant part of the organic carbon (OC) they store may be allochthonous OC that has been sequestered elsewhere. Yet, the compositions of allochthonous OC are largely unknown. Here, we present concentrations and carbon isotopic $\left({ }^{13} \mathrm{C}\right.$ and $\left.{ }^{14} \mathrm{C}\right)$ compositions and accumulation rates of carbon in the $\mathrm{VCHs}$ from major temperate-subtropical deltas of China: Yellow, Yangtze, and Pearl river deltas. We find that black carbon (BC) amounts to 9-25\% of OC across sites. Temperate VCHs exhibit lower BC contents but higher BC contributions than subtropical VCHs. This seemingly counterintuitive result can be explained by increased accumulation of long-term, stable, allochthonous $\mathrm{OC}$ in temperate VCHs. BC in temperate VCHs contains 1.5-2 times more fossil BC than that in subtropical $\mathrm{VCH}$ in the $1 \mathrm{~m}$ depth soil, which is likely influenced by atmospheric input and the aging effect. We estimate an accumulation rate of BC in China's VCHs of $33.1 \pm 14.5 \mathrm{~g} \mathrm{~m}^{-2}$ year $^{-1}$, acting as a hotspot for $\mathrm{BC}$ burial. These results point to a substantial and hitherto unquantified contribution of $\mathrm{BC}$ components to blue carbon storage, as well as the VCHs to global BC storage. Preservation of this old-aged, stable OC implies an important ecosystem service of the VCHs for climate change mitigation.

\section{INTRODUCTION}

Vegetated coastal habitats (VCHs) dominated by saltmarsh, mangrove, and seagrass sustain the highest rates of carbon sequestration per area of all natural systems, accounting for $46.9 \%$ of the annual organic carbon (OC) buried in the coastal oceans, contributing to climate change mitigation and adaptation. ${ }^{1-3}$ The OC stored is derived from multiple sources as the VCHs are located at the interface between terrestrial, riverine, estuarine, and marine ecosystems. These sources can be subdivided into (1) autochthonous OC that was derived from roots, woody tissues, and leaf litter and buried locally and (2) allochthonous OC that was derived from the terrestrial or marine ecosystems supplied by river or tide and subsequently trapped by the VCHs. ${ }^{1,4}$ The contribution of allochthonous $\mathrm{OC}$ in the $\mathrm{VCHs}$ that was dominated by mineral sediment accretion is more than $50 \% .^{4-6}$ The deposition of allochthonous particles may maintain or accelerate the OC sequestration rate by providing $\mathrm{VCH}$ accommodation space and enhancing its resilience against sea-level rise and may also stabilize OC against decomposition through the formation of OC-mineral complexes. ${ }^{3,7,8}$ Despite its importance, differentiating sources between allochthonous and autochthonous OC remains a challenge. ${ }^{9}$ In particular, the sources of allochthonous recalcitrant $\mathrm{OC}$ are not well defined.

Black carbon (BC), which is formed by incomplete combustion of fossil fuels and biomass, is increasingly being added to soils or sediments as an allochthonous recalcitrant OC through natural vegetation fires, anthropogenic pollution, and strategies for $\mathrm{C}$ sequestration ("biochar"). ${ }^{10-12}$ It has been estimated that the amount of BC accounts for 5-60\% of OC in prairie, $^{13}$ agricultural, ${ }_{18}^{14}$ peatland ${ }^{15,16}$ or forest $^{17}$ soils, $3-15 \%$ in ocean sediments, ${ }^{18}$ and up to $50 \pm 40 \%$ in coastal sediments. ${ }^{19} \mathrm{BC}$ enters the coastal sea and open ocean by rivers and atmospheric deposition. ${ }^{1,20-22}$ Globally, riverine dissolved and particulate BC can contribute approximately 10 and $15 \%$ of riverine dissolved and particulate OC flux. ${ }^{11,22}$ These dissolved and particulate materials arriving at the coast from river flows or precipitation can be efficiently preserved in the VCHs. In a recent study, Chew and Gallagher ${ }^{23}$ reported that the $\mathrm{BC}$ that likely originated from atmospheric deposition accounted for $10-25 \%$ of the OC preserved in the surface soils of mangrove and seagrass from Malaysia and Australia. However, the sources of this large amount of preserved $\mathrm{BC}$, whether from fossil fuel combustion or recent biomass burning, are not known. Furthermore, the relationships

Received: January 29, 2021

Revised: April 8, 2021

Accepted: April 8, 2021

Published: April 22, 2021

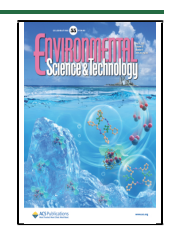




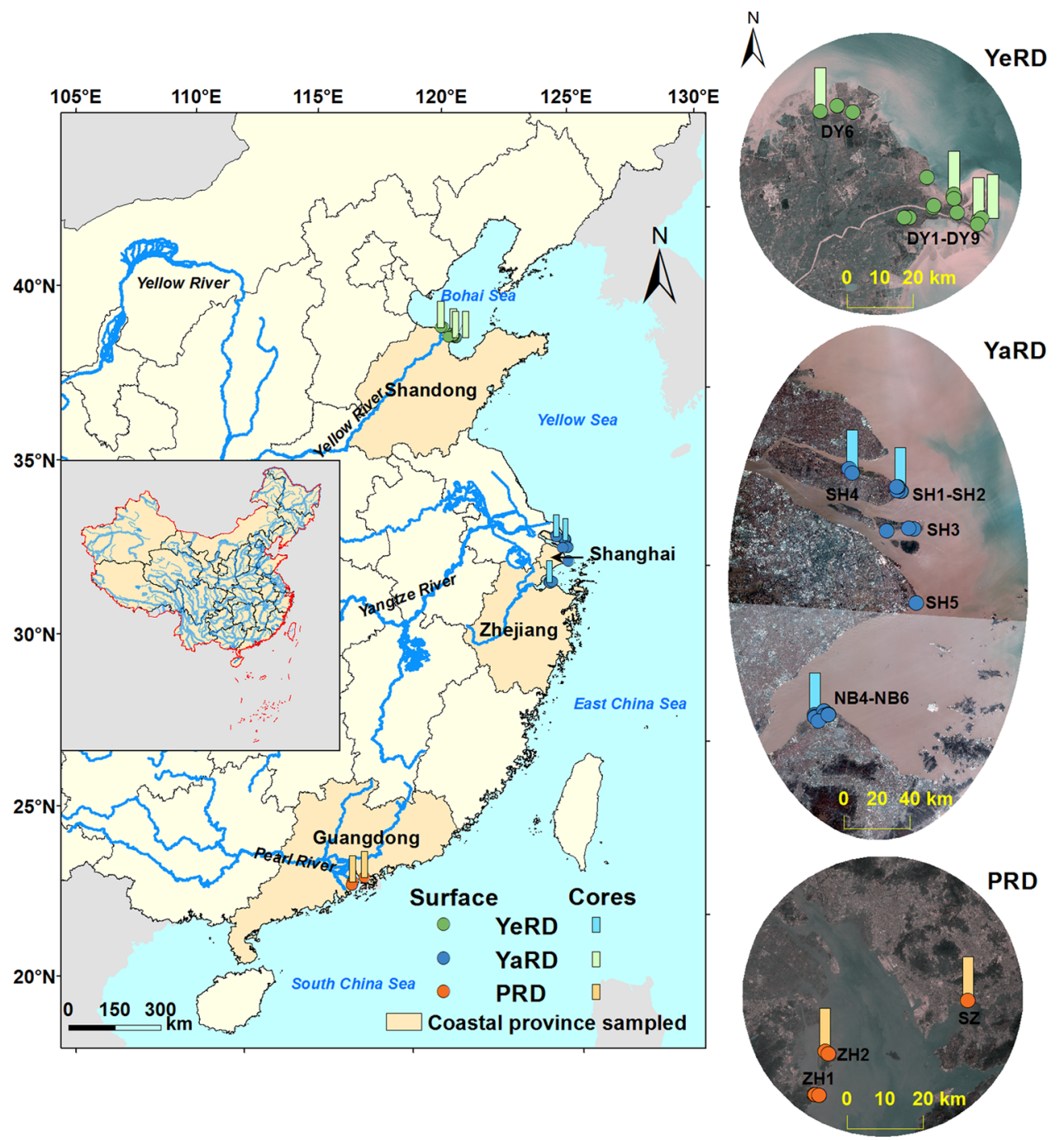

Figure 1. Sampling sites of soil cores and surface soils in the VCHs from the Yellow River Delta (YeRD), Yangtze River Delta (YaRD), and Pearl River Delta (PRD).

between $\mathrm{BC}$ and allochthonous $\mathrm{OC}$ and their accumulation rates are unclear.

The Yellow, Yangtze, and Pearl rivers are three of the world's major rivers and three largest rivers in China because of their high water discharge and sediment load. ${ }^{24}$ The VCHs are common features of their deltas and estuaries, forming efficient carbon sinks by sequestering $\mathrm{CO}_{2} .{ }^{25,26}$ The annual flux of total $\mathrm{BC}$ in the Yellow and Yangtze rivers accounts for $\sim 12.5 \%$ of total OC flux, and the two rivers transport $12.7 \%$ of $\mathrm{BC}$ produced annually in China. ${ }^{20}$ The China's river-influenced marginal seas are undoubtedly important sinks of $\mathrm{BC}^{21,27}$ of which $60-80 \%$ is derived from fossil fuel. ${ }^{28}$ However, there remains no estimate of the sources and accumulation rates of $\mathrm{BC}$ and their contributions to $\mathrm{OC}$ of the $\mathrm{VCHs}$, impeding our ability to quantitatively predict anthropogenic OC impact on the carbon cycle in coastal wetlands.

Here, we collected surface soil and soil core samples for isotope analysis in the VCHs of the Yellow, Yangtze, and Pearl river deltas. The objectives of this study were (1) to reveal the horizontal and vertical distribution pattern of BC and OC, (2) to quantitatively determine the contribution of $\mathrm{BC}$ originating from fossil fuel combustion and biomass burning to the allochthonous OC pool, and (3) to elucidate the accumulation rates of $\mathrm{BC}$ and $\mathrm{OC}$ fractions in the $\mathrm{VCHs}$ of these three key carbon cycle interfaces between land and coastal sea.

\section{MATERIALS AND METHODS}

2.1. Study Sites and Sample Collection. The Yellow, Yangtze, and Pearl rivers are the three largest rivers in China, draining one third of China's land $\left(\sim 3.1 \times 10^{6} \mathrm{~km}^{2}\right)$ and half of China's population ( $\sim 700$ million $).^{29}$ Together, they provide more than 3,9 , and $7 \%$ of world's total fresh water, sediment, and dissolved solids to the Bohai Sea, Yellow Sea, East China Sea, and South China Sea of the western Pacific Ocean. ${ }^{24}$ The high sediment flux from the three rivers has formed three mega-deltas for the last $8 \mathrm{ka}$, acting as important sinks of particulate and dissolved materials (e.g., carbon, nutrients, and pollutants) entering the ocean. ${ }^{20,21,29,30}$

The Yellow, Yangtze, and Pearl river deltas lie between $21^{\circ} \mathrm{N}$ and $40^{\circ} \mathrm{N}$ along the northwest coast of the Pacific Ocean (Figure 1). The annual average temperature and precipitation for the YeRD, YaRD, and PRD are $12.9 \pm 0.2{ }^{\circ} \mathrm{C}$ and $45.7 \pm$ $1.2 \mathrm{~mm}, 16.2 \pm 0.7{ }^{\circ} \mathrm{C}$ and $104 \pm 19 \mathrm{~mm}$, and $22.8 \pm 0.2{ }^{\circ} \mathrm{C}$ and $162 \pm 6 \mathrm{~mm}$, respectively. ${ }^{31}$ The climate varies from warm and wet in the PRD to cold and dry in the YeRD. Water discharge and sediment flux of Yellow and Yangtze rivers are 
sensitive to the impacts of climate oscillations such as El NiñoSouthern Oscillation events. ${ }^{29}$ The coastal wetland areas of the Shandong Provence, Shanghai City, and Zhejiang Provence and Guangdong Provence, which are administrative regions of the YeRD, YaRD, and PRD, contribute $40 \%$ of the China's total coastal wetlands. ${ }^{26}$ The VCHs are dominated by saltmarsh and seagrass for the YeRD, saltmarsh for the YaRD, and mangrove for the PRD. The specific vegetation types are provided in Table $\mathrm{S} 1$.

In this study, 15 surface soil samples and 4 soil cores for the YeRD, 21 surface soil samples and 3 soil cores for the YaRD, and 5 surface soil samples and 2 soil cores for the PRD were collected (Table S1) according to the method outlined by the Blue Carbon Initiative. ${ }^{32}$ Surface soil samples were collected with a corer (length $20 \mathrm{~cm}$ and diameter $5 \mathrm{~cm}$ ) from three to five randomly chosen plots separated by $15 \mathrm{~m}$ within the VCHs. The samples were packed into a polyethylene bag and transported to the laboratory at $-20{ }^{\circ} \mathrm{C}$. Soil cores were sampled using hand-operated knocking polycarbonate corers (length 130 or $170 \mathrm{~cm}$ and diameter $10 \mathrm{~cm}$ ). All cores were sealed at both ends and packaged with black plastic films and transported to the laboratory. The core samples were sliced at 2 or $5 \mathrm{~cm}$-thick intervals. Each sliced sample was kept frozen at $-20{ }^{\circ} \mathrm{C}$ before further analysis.

2.2. OC and BC Analysis. OC, BC, and total nitrogen of bulk soil were measured on a Vario MACRO cube elemental analyzer (Elementar, Germany). For OC measurement, soil samples were pretreated with $1 \mathrm{M} \mathrm{HCl}$ to remove carbonates. Quality assurance and quality control were performed using the same procedures for elements. BC was determined using the chemical oxidation method based on Lim and Cachier (Text S1). ${ }^{33}$ Briefly, $3 \mathrm{~g}$ dried bulk samples were first treated with $3 \mathrm{M} \mathrm{HCl}$ for $24 \mathrm{~h}$ to remove carbonates. After rinsing, the silicate minerals and refractory oxides were sequentially dissolved in $10 \mathrm{M} \mathrm{HF} / 1 \mathrm{M} \mathrm{HCl}$ and $10 \mathrm{M} \mathrm{HCl}$ for $24 \mathrm{~h}$ to liberate any superficial carbonaceous material, which may be trapped between the silicate sheets. After rinsing and drying, $0.3 \mathrm{~g}$ acid-treated samples were oxidized with $0.1 \mathrm{M} \mathrm{K}_{2} \mathrm{Cr}_{2} \mathrm{O}_{7}$ / $2 \mathrm{M} \mathrm{H}_{2} \mathrm{SO}_{4}$ at $55{ }^{\circ} \mathrm{C}$ for $60 \mathrm{~h}$ to remove the soluble organic matter and kerogen. Dichromate-to-carbon ratios of the soil/ oxidant mixture were kept in excess. Higher concentrations of $\mathrm{K}_{2} \mathrm{Cr}_{2} \mathrm{O}_{7}(0.5 \mathrm{M})$ were used for the PRD soil samples with high OC contents. The remaining refractory carbon left in the residue was operationally defined as $\mathrm{BC}$ ranging from char to soot. $^{34}$ The method has been successfully used for BC identification in the Yellow and Yangtze river basins and the Pearl river estuary. ${ }^{35-37}$ The reproducibility was examined using seven aliquots from one surface sample of the Yellow, Yangtze, and Pearl river deltas, respectively. Reproducibility was within $5 \%$.

The OC- and BC-containing residues were combusted in a Thermo elemental analyzer (Flash EA 1112) integrated with a ConFlo III system with a Thermo MAT253 mass spectrometer. $\delta^{13} \mathrm{C}$ was expressed as relative to the international standard of PDB. Replication had a standard deviation better than $\pm 0.1 \%$ o based on the repeated measurements of the international standard IAEA-600. Reproducibility of sample replicates was generally better than $\pm 0.2 \%$ or $\delta^{13} \mathrm{C} . \Delta^{14} \mathrm{C}$ measurements of $\mathrm{BC}$-containing residues were performed at the Beta Analytic Inc., USA, using standard Accelerator Mass Spectrometry delivery analysis. The errors of $\Delta^{14} \mathrm{C}$ measurements ranged from 1 to $3 \%$.
The morphology and chemical composition of BC particles from surface samples of the Yellow, Yangtze, and Pearl river deltas were investigated by scanning electron microscopyenergy dispersive spectroscopy (SEM-EDS, Hitachi S-4800, Japan). The residues after chemical oxidation were put on a slide and mounted onto a conductive tape holder. The sample was then gold-coated before being analyzed by SEM-EDS at 15 $\mathrm{kV}$. The element maps were used to examine the carbon distribution, and then the energy dispersive spectroscopy (EDS) composition was used to identify the BC particles.

2.3. Carbon Source Identification. The relative contribution of wetland vegetation (plant tissue), terrestrial particulate organic matter, and marine (phytoplankton and macroalgae) organic matter sources to the carbon pools in the $\mathrm{VCH}$ soil cores was estimated using Bayesian mixing models in $\mathrm{R}$ (MixSIAR) based on $\delta^{13} \mathrm{C}$ and the $\mathrm{N} / \mathrm{C}$ ratio (Text $\left.\mathrm{S} 2\right){ }^{38}$ Bayesian mixing models incorporate both observed data and uncertainty to quantify the likelihood of a given solution, which is obtained from the posterior distribution. ${ }^{38}$ The $\delta^{13} \mathrm{C}$ and $\mathrm{N} / \mathrm{C}$ values of these endmembers were determined from both our data and the published data and are provided in Table S2. We chose $\mathrm{N} / \mathrm{C}$ rather than $\mathrm{C} / \mathrm{N}$ ratios in the model because the former was statistically more robust because the higher number (OC concentration) is the denominator and behaves linearly in end-member mixtures. ${ }^{25}$ Because of the large variation of $\delta^{13} \mathrm{C}$ and $\mathrm{N} / \mathrm{C}$ among plant tissues, we used the median values because it was difficult to deduce the undisputed fractionation factor for wetland vegetation. We assumed $\mathrm{SD}=0.5$ or 0.005 to reflect similar variability of the $\delta^{13} \mathrm{C}$ or $\mathrm{N} / \mathrm{C}$ values. ${ }^{6}$ The wetland vegetation carbon was defined as autochthonous $\mathrm{OC}$, and the terrestrial carbon and marine carbon together were defined as allochthonous OC.

The contributions of fossil fuel combustion sources and biomass burning sources to the $\mathrm{BC}$ pool were determined using the isotopic mass balance equation (Text S2):

$$
\Delta^{14} C_{\text {sample }}=f_{\text {fossil }} \times \Delta^{14} C_{\text {fossil }}+\left(1-f_{\text {fossil }}\right) \times \Delta^{14} C_{\text {biomass }}
$$

where $\Delta^{14} \mathrm{C}_{\text {sample }}$ represents the measured $\Delta^{14} \mathrm{C}$ value of $\mathrm{BC}$ at each depth, and $\Delta^{14} \mathrm{C}_{\text {fossil }}$ and $\Delta^{14} \mathrm{C}_{\text {biomass }}$ represent the $\Delta^{14} \mathrm{C}$ values of $\mathrm{BC}$ from fossil fuel combustion and biomass burning. We assumed that $\mathrm{BC}$ derived from fossil fuel combustion had a ${ }^{14} \mathrm{C}$-free $\Delta^{14} \mathrm{C}$ value of $-1000 \pm 0 \%$, and $\mathrm{BC}$ produced from biomass burning had a postbomb $\Delta^{14} \mathrm{C}$ value of $112 \pm 60 \%$. ${ }^{39}$

2.4. Carbon Accumulation Rate Calculation. Four soil cores (DY7, SH4-2, NB4-2, and SZ) sliced at $2 \mathrm{~cm}$-thick intervals from the deltas were analyzed for ${ }^{210} \mathrm{~Pb}$ activities to determine last century sediment accumulation rates (SARs). The ${ }^{210} \mathrm{~Pb}$ results are provided in Figure S1. Determination of ${ }^{210} \mathrm{~Pb}$ activities was conducted using an EG \& G Ortec HPGe GWL gamma-ray spectrometer (Ametek Inc., UAS). The total ${ }^{210} \mathrm{~Pb}$ and ${ }^{226} \mathrm{Ra}$ activities were measured at 46.5 and $295.2 \mathrm{keV}\left({ }^{214} \mathrm{~Pb}\right)$, respectively. Excess ${ }^{210} \mathrm{~Pb}\left({ }^{210} \mathrm{~Pb}\right.$ ex $)$ was calculated by subtracting ${ }^{226} \mathrm{Ra}$ activity from total ${ }^{210} \mathrm{~Pb}$ activity. The constant rate of supply model was used for the determination of the mass accumulation rate (MAR) of each section. ${ }^{40}$ We used the soil carbon content and SAR to calculate carbon accumulation rates (CARs) in soils of VCHs. Soil carbon stocks in VCHs were quantified by multiplying OC and $\mathrm{BC}$ and dry bulk density. Dry bulk density was determined as a simple dry weight-to-volume ratio. The soil $\left(10 \mathrm{~cm}^{3}\right)$ was taken from each $5 \mathrm{~cm}$-thick slice using a syringe and dispensed 
(a)
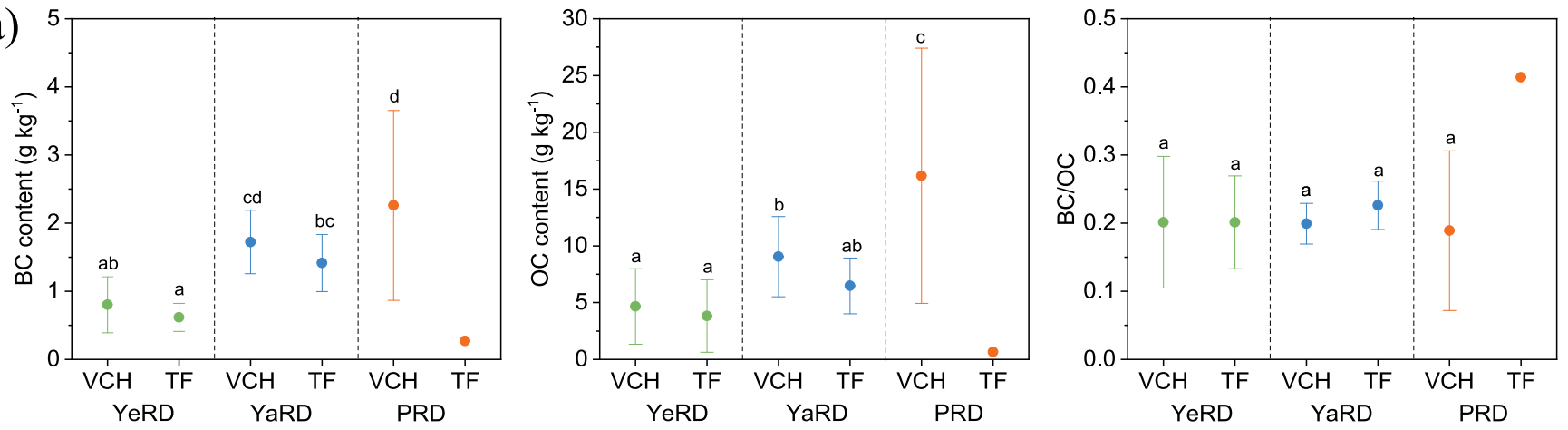

(b)

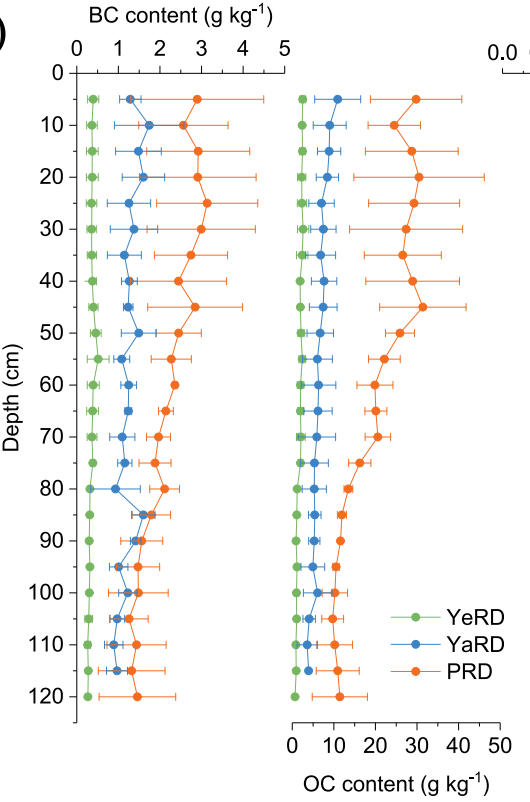

$\mathrm{BC} / \mathrm{OC}$
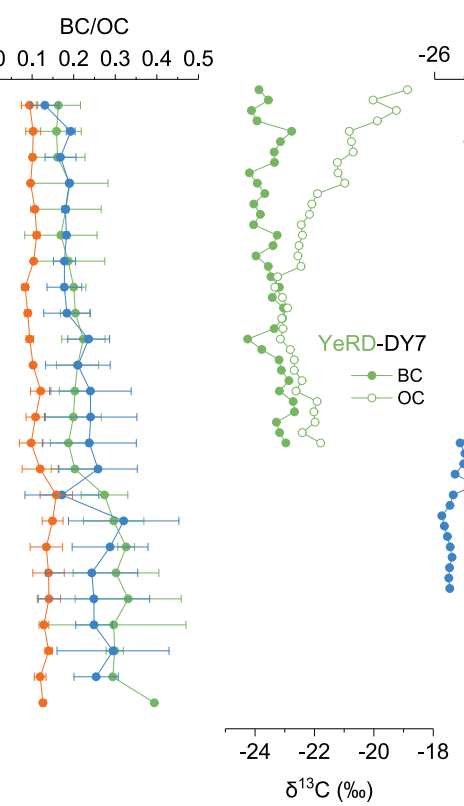

$\delta^{13} \mathrm{C}(\%)$

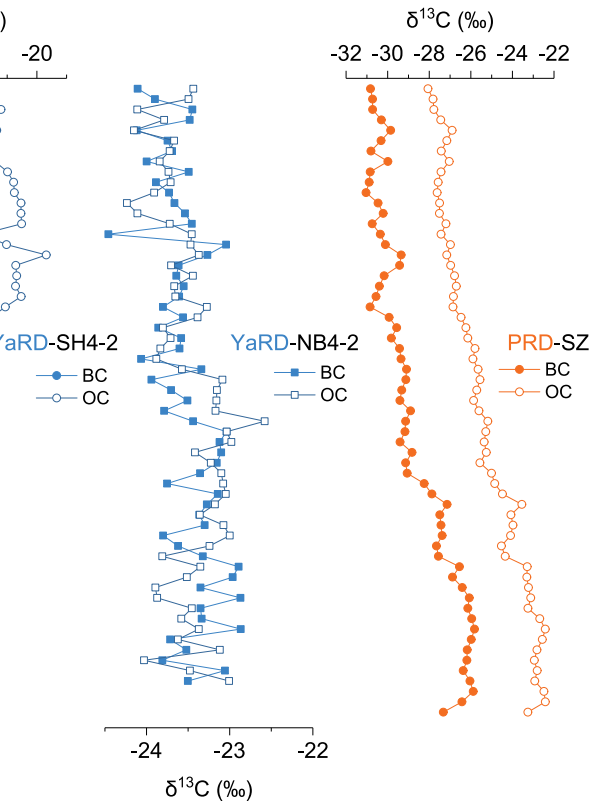

Figure 2. Comparison of $\mathrm{BC}$ content, $\mathrm{OC}$ content, $\mathrm{BC} / \mathrm{OC}$ ratio, $\delta^{13} \mathrm{C}_{\mathrm{BC}}$, and $\delta^{13} \mathrm{C}_{\mathrm{OC}}$ in (a) VCHs and TF topsoils and in (b) VCH soil cores in the YeRD, YaRD, and PRD. The error bars correspond to 1 s.d. for samples collected on different ecosystems or soil depths. The mean values of TF samples in the PRD are based on two replicates.

onto a preweighed container and then oven-dried to constant weight at $60{ }^{\circ} \mathrm{C}$.

2.5. Statistical Analysis. The data were statistically analyzed using SPSS Statistics 20.0 for windows (SPSS Inc., Chicago, IL, USA). Analysis of variance was employed to test the differences between vegetated and unvegetated coastal habitats. Pearson correlation analysis was conducted to detect relationships among the variables investigated.

\section{RESULTS AND DISCUSSION}

3.1. Distribution Patterns of BC. The mean BC and OC concentrations in the $\mathrm{VCH}$ topsoils of the YeRD, YaRD, and PRD were $0.80 \pm 0.41 \mathrm{~g} \mathrm{~kg}^{-1}$ and $4.66 \pm 3.3 \mathrm{~g} \mathrm{~kg}^{-1}, 1.72 \pm$ $0.47 \mathrm{~g} \mathrm{~kg}^{-1}$ and $9.05 \pm 3.53 \mathrm{~g} \mathrm{~kg}^{-1}$, and $2.26 \pm 1.39 \mathrm{~g} \mathrm{~kg}^{-1}$ and $16.2 \pm 11.2 \mathrm{~g} \mathrm{~kg}^{-1}$, respectively (Figure 2a, Table S3). Both $\mathrm{BC}$ and $\mathrm{OC}$ concentrations significantly increased from the YeRD, YaRD, to PRD. The OC values were consistent with our national estimates, with higher OC storage capacity of tidal marshes and mangroves occurring in the tropics and south subtropics. ${ }^{25} \mathrm{BC} / \mathrm{OC}$ ratios in the $\mathrm{VCH}$ topsoils of the YeRD, YaRD, and PRD are in the range of 0.09-0.47, 0.15-0.24, and $0.18-0.26$. The results are in agreement with those reported previously in the suspended particles of the Yellow river (0.09-0.45) and Yangtze river (0.12-0.13) and the sediments of the Pearl river estuary $(0.13-0.29) .{ }^{20,35}$ This indicates that terrestrial $\mathrm{BC}$ export from land to the coasts is an important pathway for $\mathrm{BC}$ deposition and preservation in the coastal soils and sediments. However, no significant differences in $\mathrm{BC} / \mathrm{OC}$ ratios of the $\mathrm{VCH}$ soils were detected among the three river deltas. This is different from the dissolved and particulate BC that has higher $\mathrm{BC} / \mathrm{OC}$ ratios in the Yellow river than the Yangtze river. ${ }^{20}$ The $\mathrm{BC}$ and $\mathrm{OC}$ concentrations in the VCHs were relatively higher than those in the unvegetated tidal flat (TF) but showing no significant difference. The TF in the PRD is largely reclaimed for urban expansion and is dominated by sandy beach with quite low OC concentration but a high $\mathrm{BC} / \mathrm{OC}$ ratio, which may be attributed to the degradation of $\mathrm{OC}$ and the aeolian supply of BC to low OC content sandy soils. $^{23}$

For the whole soil cores, the mean values of $\mathrm{BC}$ and $\mathrm{OC}$ concentrations and stocks were highest in the PRD (BC: 22.1 $\mathrm{Mg} \mathrm{ha} \mathrm{h}^{-1}$ and OC: $204 \mathrm{Mg} \mathrm{ha}^{-1}$ ) followed by the YaRD (BC: $15.7 \mathrm{Mg} \mathrm{ha}^{-1}$ and OC: $81.6 \mathrm{Mg} \mathrm{ha}^{-1}$ ) and YeRD (BC: 6.15 $\mathrm{Mg} \mathrm{ha}^{-1}$ and OC: $28.4 \mathrm{Mg} \mathrm{ha}^{-1}$ ), respectively (Figure $2 \mathrm{~b}$, Table S4). The specific distribution patterns are provided in Figure S2. The OC concentrations gradually decreased with depth in the three deltas. In the YeRD, higher OC and highest BC concentrations were observed in subsoils at a depth of 
$\sim 50-70 \mathrm{~cm}$, which can be attributed to the occurring of the so-called red clay layer with high element accumulation capacity because of the highly reactive mineral contents in this depth range. ${ }^{41}$ The $\mathrm{BC}$ and $\mathrm{OC}$ concentrations were well correlated in the PRD while the $\mathrm{BC}$ concentrations fluctuated more in the soil cores of the YeRD and YaRD. The BC concentrations were about 1.5 times higher in the top $50 \mathrm{~cm}$ than that in the $50-120 \mathrm{~cm}$ of the PRD, and they were approaching that in the $80-120 \mathrm{~cm}$ of the YaRD. The depth profiles of $\mathrm{BC} / \mathrm{OC}$ ratios were remarkably different from the $\mathrm{BC}$ and $\mathrm{OC}$ concentrations. The $\mathrm{BC}$ and $\mathrm{OC}$ concentrations decreased with depth while the $\mathrm{BC} / \mathrm{OC}$ ratios were increased. These increases in $\mathrm{BC} / \mathrm{OC}$ ratios are generally because $\mathrm{OC}$ is more likely degraded by disturbance while $\mathrm{BC}$ as a more refractory fraction will likely be preserved. ${ }^{3,22}$ The concentrations of $\mathrm{BC}$ and $\mathrm{OC}$ were highest in the PRD while the $\mathrm{BC} /$ OC ratios were the lowest (Table S4). These patterns suggest that OC-mineral complex adsorption may be an important mechanism for BC stabilization in coastal soils because of the relatively low OC concentrations of the YeRD and YaRD reflecting the mineral-dominated nature of these two soils. ${ }^{42}$

3.2. Preservation Mechanisms of BC. In our dataset, good linear relationships are observed between $\mathrm{BC}$ and $\mathrm{OC}$ (Figure S3a) and between $\mathrm{BC} / \mathrm{OC}$ and allochthonous or autochthonous OC/OC (Figure 3, Figure S3b). This positive

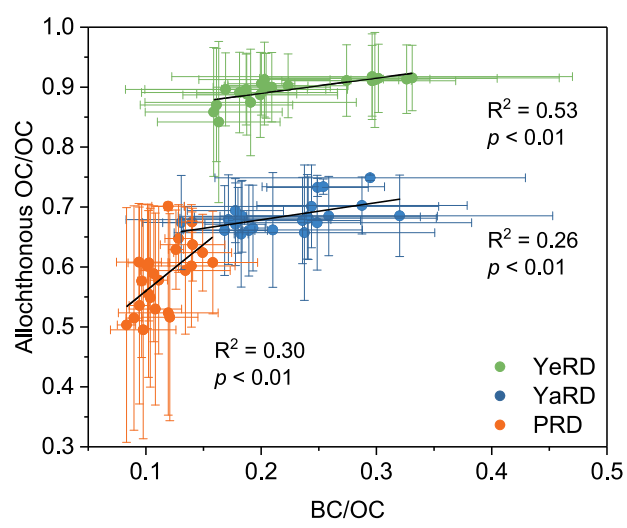

Figure 3. Relationships between allochthonous OC/total OC and $\mathrm{BC} / \mathrm{OC}$ in the VCH soils of the YeRD, YaRD, and PRD. The data are mean $( \pm$ s.d.) values of soil cores with an interval of $5 \mathrm{~cm}$.

relationship is also observed in global rivers, grassland soils, and coastal soils, ${ }^{11,23,42}$ suggesting that $\mathrm{OC}$ is an important environmental intermediate for transfer and storage of BC. Our results show that the majority of preserved OC in deltaic $\mathrm{VCHs}$ is allochthonous OC that has a terrestrial or marine origin (Figure 3, Figure S2). The allochthonous OC deposited in estuarine deltas is likely to be quite stable as it is eroded from terrestrial ecosystems and transported as cohesive organo-mineral aggregates through the river system., ${ }^{3,4}$ The average contributions of allochthonous OC were $87.5 \%$ (62.2$96.8 \%), 68.1 \%(65.4-75.1 \%)$, and $52.9 \%(29.5-70.2 \%)$ in $1 \mathrm{~m}$ depth profiles of the YeRD, YaRD, and PRD, respectively. The high percentages of allochthonous OC are according to our previous findings that Chinese VCHs have high terrestrial sediment inputs but low soil OC stocks. ${ }^{25}$ Importantly, the percentages of allochthonous OC significantly decreased from temperate delta to south subtropical delta. In the YeRD topsoil $(0-20 \mathrm{~cm}), \mathrm{OC}$ is a mixture between this allochthonous OC and locally produced biomass (autochthonous OC) (Figure
S2). ${ }^{25}$ In the subtropical region, higher temperature and precipitation enhance primary production of coastal vegetation and soil inundation periods, ${ }^{43,44}$ resulting in higher autochthonous OC stocks in the YeRD and PRD. Moreover, the productivity and sediment trap capabilities of mangrove grown in the south subtropical/tropical estuary are higher than those of saltmarsh grown in the temperate/north subtropical estuary. ${ }^{1}$ The results suggest that preservation of short-term, labile, autochthonous OC is more important in the south subtropical/tropical estuary compared to the temperate estuary. In contrast, in temperate/north subtropical saltmarshes, the majority of preserved OC has not been sequestered in situ but controlled by the supply of longterm, stable, allochthonous OC associated with mineral sediments from terrestrial and marine origin.

According to SEM-EDS observations, the morphology of BC from the YeRD and YaRD is dominated by irregular polyhedra and block shape, indicating its origin from oil or coal burning processes, whereas that from the PRD occurs as flaky and laminated aggregates, suggesting its possible derivation from incomplete burning of plant or coal materials (Figure 4). ${ }^{45}$ The $\mathrm{BC}$ grain size is generally in the range of $10-20 \mu \mathrm{m}$. The different morphology and similar grain size indicate different sources and a thorough mixing process before deposition. It is worth pointing out that $\mathrm{BC}$ from coastal VCHs is always associated with silicate minerals as indicated by the relatively high abundance of elemental silicon and aluminum besides carbon in the EDS (Figure 4). In principal component analysis (PCA), the variability of $\mathrm{BC}$ and $\mathrm{OC}$ concentrations can be largely explained by the heavy metals (Figure S4), suggesting that the anthropogenic processes driving the release and transport of $\mathrm{OC}$ and $\mathrm{BC}$ are related. These results support our hypothesis that allochthonous particle deposition and mineral interaction are important for BC preservation over a long timeframe. The allochthonous inputs and physical protection are also important mechanisms for OC preservation in regions with high mineral sediments and/or fine-grained particle delivery. ${ }^{3}$ However, the stability of early formed oxidized BC would benefit little from adsorption to minerals because BC generated at high heating temperatures generally exhibits highly condensed aromatic structures and very low polarity. Therefore, aging of BC during transportation with allochthonous particles seems critical in facilitating its preservation because the condensed aromatic structures of $\mathrm{BC}$ can be functionalized over time with hydroxyl and carboxylic groups. ${ }^{46}$ Moreover, allochthonous OC could be directly involved in the physical transportation and deposition process of $\mathrm{BC}$ through hydrophobic interactions. ${ }^{16}$

3.3. Sources of $\mathrm{BC}$. The $\delta^{13} \mathrm{C}$ and $\Delta^{14} \mathrm{C}$ dual-carbon isotope compositions and contents of $\mathrm{BC}$ are compared for three delta VCHs in Figure 5a and yield three interesting findings. First, a good linear correlation exists between $\delta^{13} \mathrm{C}$ and $\Delta^{14} \mathrm{C}$ in the whole dataset. Second, highest concentrations of $\mathrm{BC}$ at the PRD are characterized by lowest $\delta^{13} \mathrm{C}$ and highest $\Delta^{14} \mathrm{C}$, while $\mathrm{BC}$ at the YeRD shows opposite patterns. Third, high concentrations of $\mathrm{BC}$ at the PRD are associated with lower $\Delta^{14} \mathrm{C}$ ages and higher biomass contributions, while the $\Delta^{14} \mathrm{C}$ ages and fossil contributions are increased in the YaRD and reach highest levels in the YeRD (Table S5). We note that the ages of $\mathrm{BC}(13270-17,620 \mathrm{BP})$ are 2-100 times older than those of bulk OC (modern-9830 BP) in the YeRD, ${ }^{47}$ indicating that $\mathrm{BC}$ in soil $\mathrm{OC}$ of the minerogenic $\mathrm{VCH}$ is not of recent biologic origin; instead, they are preaged before it is 

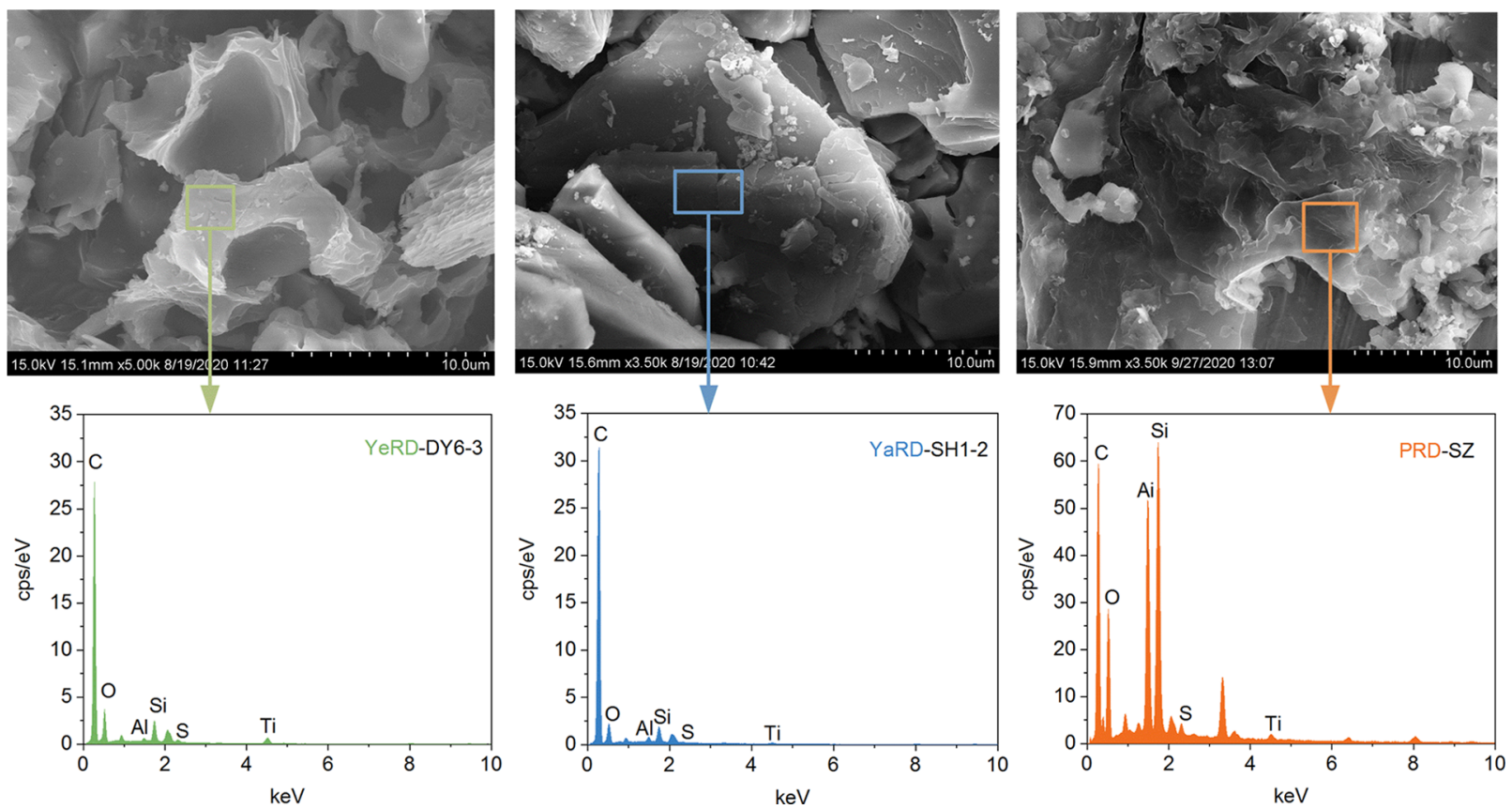

Figure 4. SEM-EDS results of $\mathrm{BC}$ from the VCH topsoils of the YeRD, YaRD, and PRD.

incorporated into the OC pools. There are increasing trends of $\delta^{13} \mathrm{C}$ and decreasing trends of $\Delta^{14} \mathrm{C}$ in both the aerosol BC and riverine $\mathrm{BC}$ from northern China coast to southern China coast; ${ }^{20,39}$ however, such a good correlation is not observed in their studies. This suggests that BC preserved in China's coastal deltas has similar sources but different relative source contributions along the latitude gradient.

In Figure 5b, we synthesize a three OC-source (autochthonous, terrestrial-derived, and marine-derived) Bayesian mixing model and a two BC-source (biomass-derived and fossil-derived) mass balance model to estimate the contribution of autochthonous OC, non-BC allochthonous OC, fossil $\mathrm{BC}$, and biomass $\mathrm{BC}$ to the bulk OC pools (Text S2). There is a clear gradient in the source of these carbon fractions along the coastal deltas. The relative contribution of autochthonous OC of the YaRD and PRD is 3-4 times higher than that of the YeRD, while non-BC allochthonous $\mathrm{OC}$ is 1.5 times lower. The relative contributions of biomass $\mathrm{BC}$ gradually increase from the YeRD to the PRD, but the contributions of fossil BC greatly decrease toward the PRD. This suggests a dramatic increase in coal-fired activities for coal-based industries and household heating in northern China as relative contributions of liquid fossil combustion are similar between northern and southern China. $^{21,39}$

The relative contributions of non-BC allochthonous $\mathrm{OC}$ and biomass $\mathrm{BC}$ are similar for depth layers. The surface soil layer $(0-20 \mathrm{~cm})$ has highest autochthonous OC relative contributions compared to those at subsoil layers of the YeRD and YaRD. In the PRD, however, highest autochthonous OC relative contributions occur at the middle soil layer (30-60 $\mathrm{cm})$. The relative contributions of fossil $\mathrm{BC}$ are higher in the bottom layer $(70-100 \mathrm{~cm})$ than those at shallower depths. BC content is often higher in deeper layers of mineral soils as well as organic soils when it is drained. ${ }^{10,16}$ The downward transport of $\mathrm{BC}$ in dissolved and particulate form could be an important mechanism for larger BC content in deeper layers. $^{48}$ Alternatively, stronger mineral-BC interactions in deeper, more stable layers are less likely to be affected by disturbances and facilitate long-term stabilization.

Clearly, the relative contributions of $\mathrm{BC}$ in the YeRD (16$21 \%)$ and YaRD VCHs (16-25\%) are much higher than that in the PRD VCHs (9-13\%). Combining the lower autochthonous OC and higher allochthonous $\mathrm{OC}$ in the YeRD and YaRD, the results further confirm that the preservation of $\mathrm{BC}$ is mainly controlled by the supply of allochthonous materials. Another notable result is that the relative contributions of non-BC allochthonous OC are remarkably constant between the YaRD and PRD. The YaRD and PRD as two metropolitan areas are also hotspots of BC emission in China. ${ }^{49}$ This stresses the importance of BC preserved in the $\mathrm{VCH}$ s with relatively high primary production that $\mathrm{BC}$ seems to be an important carbon fraction affecting the contribution of allochthonous OC to total OC storage and the stability of OC. The ${ }^{14} \mathrm{C}$-based isotope mass balance model reveals that $88 \pm 2 \%, 75 \pm 6 \%$, and $43 \pm 21 \%$ of $\mathrm{BC}$ in the YeRD, YaRD, and PRD VCHs, respectively, are derived from fossil fuel combustion, and $12 \pm 2 \%, 25 \pm 6 \%$, and $57 \pm 21 \%$ of $\mathrm{BC}$ are derived from biomass burning (Table S5). The contributions of fossil fuel combustion for the YeRD and YaRD VCHs are much higher compared with those for the Yellow and Yangtze rivers, for which Wang et al. ${ }^{20}$ reported that 52 and $49 \%$ of particulate BC and 22 and $15 \%$ of dissolved $\mathrm{BC}$ were from fossil fuel origin, whereas the large contributions of fossil fuel combustion in the deltaic VCHs are in agreement with that in the aerosols $(\sim 70-80 \%)$ at the North China Plain, YaRD, and PRD. ${ }^{21,39,50}$ These results are in accordance with previous studies, suggesting that aerosol $\mathrm{BC}$ plays a significant role in transporting $\mathrm{BC}$ to the sediments in coastal regions. $^{21,23,51,52}$ However, the aerosol derived BC cannot fully explain the $\mathrm{BC}$ sources in $\mathrm{VCH}$ s soils because the riverine OC has been proved to be a dominant OC source in the delta front estuary, ${ }^{25,30}$ and it is also an important driver for BC dynamics. ${ }^{11,20}$ An alternative explanation could be an aging effect that preaged $\mathrm{BC}$ can be incorporated into riverine OC and then accumulation and long-term aging in deltaic 

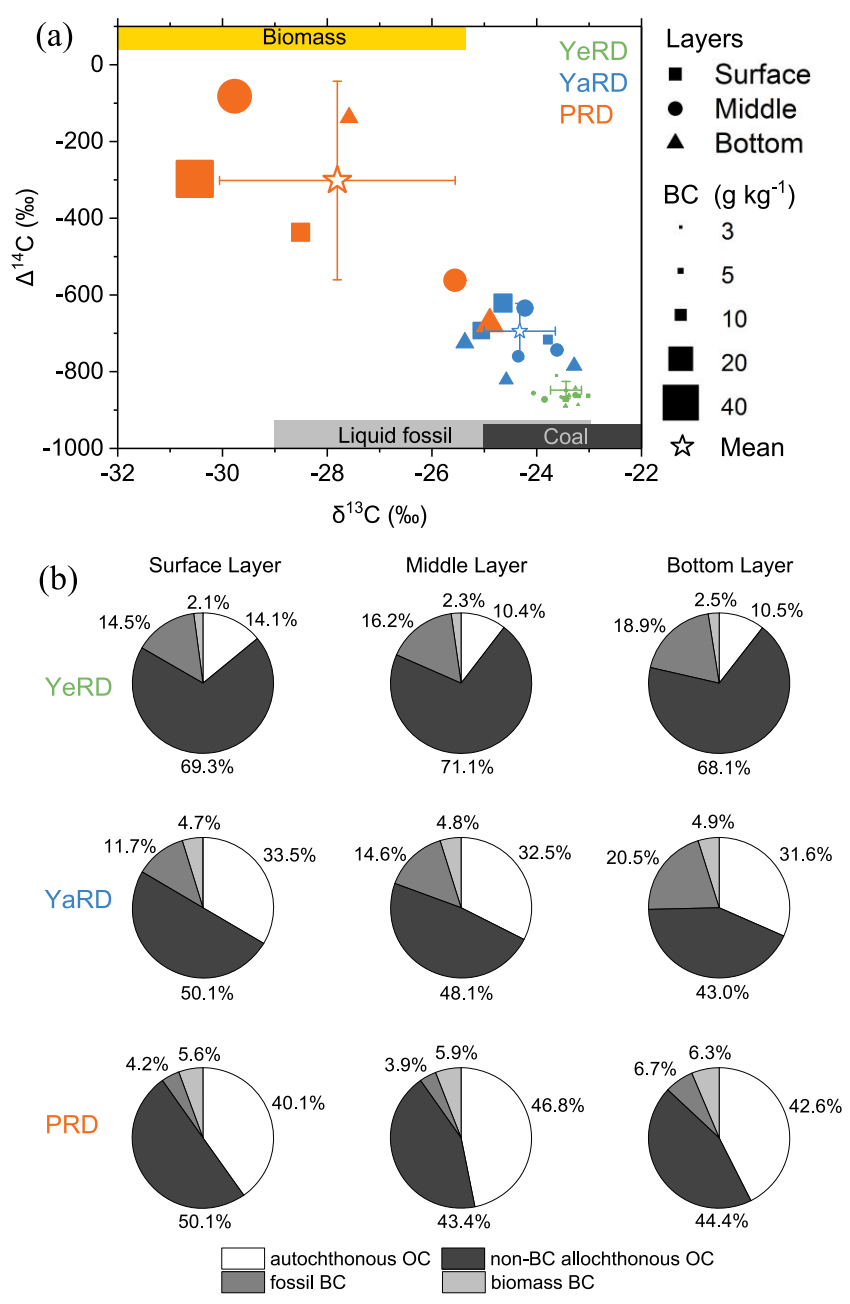

Figure 5. (a) Plot of $\Delta^{14} \mathrm{C}$ vs $\delta^{13} \mathrm{C}$ values for $\mathrm{BC}$ and (b) relative source contributions of carbon in the $\mathrm{VCH}$ soils of the YeRD, YaRD, and PRD. The sizes of the symbols for BC loadings at the different deltas reflect its contents. The stars and error bars denote $\Delta{ }^{14} \mathrm{C}$ (mean \pm s.d.) vs $\delta^{13} \mathrm{C}$ (mean \pm s.d.) in each delta.

VCHs. ${ }^{11,22}$ The increased BC ages from the PRD to YeRD VCHs (Table S5) also suggest that a large portion of $\mathrm{BC}$ is preaged before deposition in the Yellow river basin, where preaged and fossil OC contribute most (87\%) to particulate OC pools. ${ }^{53}$

3.4. Accumulation Rates of BC. The Yellow, Yangtze, and Pearl rivers in East Asia are important contributors of terrestrial sediment to the western Pacific Ocean, accounting for nearly $10 \%$ of the global sediment flux. ${ }^{29}$ The abundant sediment supply from these big rivers has contributed to the high rate of carbon accumulation, showing a linear relationship between OC or BC accumulation rates and SARs (Figure S5).
Sediment flux is thus of primary importance in influencing the changing balance between inputs and losses of China's VCH OC fractions in the past three decades (Text S3, Figure S6). Previous studies have confirmed that carbon is very efficiently preserved in fluvial systems characterized by rapid sediment transfer to the ocean, such as Ganges-Brahmaputra and Mississippi systems. ${ }^{54,55}$ The average SARs of the three delta VCHs are $\sim 3$ to 6 times (Table 1) faster than the sea-level rise in China $\left(2.9 \pm 0.8 \mathrm{~mm} \mathrm{year}^{-1} \text { and } 1980-2016\right)^{56}$ and $\sim 2$ to 5 times faster than global VCH average values. ${ }^{1}$ In global deltas, only 18 out of 54 deltas have been gaining area over the last three decades. ${ }^{57}$ Among these, accretion rates of the Yangtze, Pearl, and Yellow rank first, second, and fifth, respectively. Therefore, in these deltas, sufficient sediment inputs increase accommodation space for wetland vegetation, allowing for long-term maintenance of high CARs and ranking them as one of the major "hotspots" for BC burial in global coasts (Figure S7).

The average $\mathrm{BC}$ accumulation rates in the YeRD, YaRD, and PRD account for $11-18 \%$ of total OC accumulation rates and $21-30 \%$ of allochthonous (sum of terrestrial and marine) OC accumulation rates (Table 1). Based on these estimates, the average $\mathrm{BC}$ accumulation rates in China's VCHs are calculated to be $33.1 \pm 14.5 \mathrm{~g} \mathrm{~m}^{-2}$ year $^{-1}$. The current total areas of salt marsh, mangrove, and seagrass are estimated to be 2241.3 $\mathrm{km}^{2} .^{25,26}$ The China's VCHs occupy only $\sim 0.02 \%$ of mainland area burying $3.8 \%$ of the $1.96 \mathrm{Tg} \mathrm{BC}$ produced annually in China. ${ }^{48}$ Although $\mathrm{BC}$ does not contribute to active removal of atmospheric $\mathrm{CO}_{2}$, preservation of this large portion of carbon in $\mathrm{VCH}$ soils implies an important climate change mitigation mechanism, as well as ecosystem service of the VCHs. That is, the VCHs not only act as active atmospheric $\mathrm{CO}_{2}$ sinks though autochthonous inputs, but also serve as preservations for allochthonous carbon that has been sequestered elsewhere. In addition, our results have indicated that the TF in front of or among the VCHs is a potential $\mathrm{BC}$ burning hotspot because of the comparable $\mathrm{BC}$ contents and $\mathrm{BC} / \mathrm{OC}$ ratios with the VCHs (Figure 2a). The area of China's TF is determined to be $5379.8 \mathrm{~km}^{2},{ }^{26}$ annually storing $9.0 \%$ of the BC assuming the same accumulation rates as the VCHs. In total, an estimated $0.25 \mathrm{Tg}$ year $^{-1}$ of $\mathrm{BC}$ is stored within coastal wetlands of China, accounting for $12.8 \%$ of annually produced BC. The large burial efficiency is reasonable because rivers are dominant transfer media of BC to marginal seas, with Yellow and Yangtze rivers transporting $12.7 \%$ of the $\mathrm{BC}$ produced annually in China. ${ }^{20}$ The coastal wetlands thus serve as a significant sink of anthropogenic carbon. However, an undeniable fact is massive losses of coastal ecosystems in China over the past decades, ${ }^{58}$ with a $59 \%$ overall loss of salt marsh from the 1980s to the 2010s. ${ }^{59}$ Recently, China's government has initiated a suite of protective actions to protect and restore coastal ecosystems, ${ }^{58}$

\section{Table 1. Average MAR, SAR, and CARs in the VCHs of Each River Delta and China}

\begin{tabular}{|c|c|c|c|c|c|c|c|c|}
\hline & $\begin{array}{c}\text { MAR } \\
\left(\mathrm{kg} \mathrm{m}^{-2} \text { year }^{-1}\right)\end{array}$ & $\begin{array}{c}\text { SAR } \\
\left(\mathrm{mm} \mathrm{year}^{-1}\right)\end{array}$ & $\begin{array}{c}\text { CAR }_{\text {AutoOC }} \\
\left(\mathrm{g} \mathrm{m}^{-2} \text { year }^{-1}\right)\end{array}$ & $\begin{array}{c}\mathrm{CAR}_{\text {TerrOC }} \\
\left(\mathrm{g} \mathrm{m}^{-2} \text { year }^{-1}\right)\end{array}$ & $\begin{array}{c}\left.\mathrm{gAR}_{\mathrm{MarOC}}^{-2} \text { year }^{-1}\right) \\
\mathrm{C} \mathrm{m}\end{array}$ & $\frac{\text { CAR }_{\mathrm{BC}}}{\left(\mathrm{g} \mathrm{m}^{-2} \text { year }^{-1}\right)}$ & $\begin{array}{c}\text { CAR }_{\text {fossilBC }} \\
\left(\mathrm{g} \mathrm{m}^{-2} \text { year }^{-1}\right)\end{array}$ & $\begin{array}{l}\mathrm{CAR}_{\text {biomass BC }} \\
\left(\mathrm{g} \mathrm{m}^{-2} \text { year }^{-1}\right)\end{array}$ \\
\hline YeRD & $15.5 \pm 6.7$ & $10.5 \pm 4.4$ & $3.6 \pm 2.8$ & $19.3 \pm 7.6$ & $7.6 \pm 4.2$ & $5.6 \pm 1.5$ & $4.9 \pm 1.3$ & $0.7 \pm 0.2$ \\
\hline YaRD & $13.2 \pm 6.1$ & $12.3 \pm 5.7$ & $31.8 \pm 21.6$ & $36.6 \pm 16.3$ & $24.6 \pm 5.0$ & $18.3 \pm 3.4$ & $13.6 \pm 1.7$ & $4.8 \pm 1.8$ \\
\hline PRD & $11.4 \pm 6.6$ & $18.2 \pm 9.8$ & $97.8 \pm 54.0$ & $73.9 \pm 19.4$ & $54.5 \pm 32.2$ & $26.9 \pm 5.9$ & $11.1 \pm 3.8$ & $15.8 \pm 9.6$ \\
\hline China $^{a}$ & $18.4 \pm 16.2$ & $17.0 \pm 15.0$ & $59.0 \pm 14.3$ & $79.2 \pm 18.8$ & $56.5 \pm 18.2$ & $33.1 \pm 14.5$ & $24.3 \pm 6.7$ & $8.8 \pm 6.6$ \\
\hline
\end{tabular}

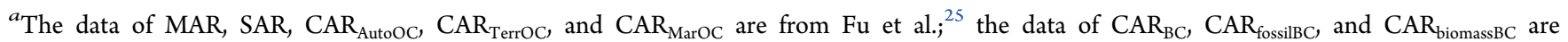
extrapolated from the average values of $\mathrm{BC}$, fossil $\mathrm{BC}$, and biomass $\mathrm{BC}$ in this study. 
such as setting up protected areas, drawing marine ecological redlines and freezes on new reclamation developments, and suggesting further potential for maintaining and enhancing the capacity of the VCHs to act as anthropogenic carbon sinks.

Our study provides the first thorough description of sources and accumulation rates of $\mathrm{BC}$ in VCHs. The average ${ }^{14} \mathrm{C}$ ages of $\mathrm{BC}$ in $\mathrm{VCHs}$ significantly decreased from temperatetemperate/north subtropical deltas (Yellow, 15,907 \pm 1130 BP; Yangtze, 10,421 $\pm 1935 \mathrm{BP})$ to south subtropical delta (Pearl, $4097 \pm 3247 \mathrm{BP}$ ). The results reveal evidence that the relative contributions of biomass $\mathrm{BC}$ gradually increase from the Yellow to the Pearl river delta, but the contributions of fossil BC greatly decrease toward the Pearl river delta. Allochthonous particle deposition and mineral interaction are important for $\mathrm{BC}$ preservation over a long timeframe because the majority of preserved $\mathrm{OC}$ in the temperate $\mathrm{VCHs}$ has an allochthonous origin associated with deposited minerals. Another interesting finding in our study is that the relative contributions of non-BC allochthonous OC are similar for depth layers and remarkably constant between the Yangtze and Pearl river delta. This indicates that $\mathrm{BC}$ is an important carbon fraction affecting the contribution of allochthonous $\mathrm{OC}$ to total OC storage. Sediment flux is of importance in influencing CARs. In addition to VCHs, unvegetated TFs are potential BC burring hotspots because of the comparable $\mathrm{BC}$ contents and $\mathrm{BC} / \mathrm{OC}$ ratios. We calculated that together the $\mathrm{VCH}$ and unvegetated TFs stored $12.8 \%$ of annually produced BC in China.

\section{ASSOCIATED CONTENT}

\section{(s) Supporting Information}

The Supporting Information is available free of charge at https://pubs.acs.org/doi/10.1021/acs.est.1c00636.

Detailed BC isolation procedure; detailed calculation methods of carbon components; temporal variations of OC and $\mathrm{BC}$; sample descriptions; $\delta^{13} \mathrm{C}$ values and $\mathrm{N} / \mathrm{C}$ ratios of endmembers; main properties of topsoil samples; concentrations and stocks of $\mathrm{BC}$ and $\mathrm{OC}$; $\Delta^{14} \mathrm{C}$ and $\delta^{13} \mathrm{C}$ values; concentration profiles of ${ }^{210} \mathrm{~Pb}$; depth distributions of carbon components; correlations between BC and OC; PCA for carbon and soil properties; and accumulation rates and temporal variations of $\mathrm{BC}$ and $\mathrm{OC}(\mathrm{PDF})$

\section{AUTHOR INFORMATION}

\section{Corresponding Author}

Yongming Luo - CAS Key Laboratory of Coastal Environmental Processes and Ecological Remediation, Yantai Institute of Coastal Zone Research (YIC), Chinese Academy of Sciences (CAS); Shandong Key Laboratory of Coastal Environmental Processes, YICCAS, Yantai 264003, China; CAS Key Laboratory of Soil Environment and Pollution Remediation, Institute of Soil Science, Chinese Academy of Sciences (CAS), Nanjing 210008, China; Center for Ocean Mega-Science, Chinese Academy of Sciences, Qingdao 266071, China; Phone: +86-25-86,881,101; Email: ymluo@issas.ac.cn

\section{Authors}

Yuan Li - CAS Key Laboratory of Coastal Environmental Processes and Ecological Remediation, Yantai Institute of Coastal Zone Research (YIC), Chinese Academy of Sciences
(CAS); Shandong Key Laboratory of Coastal Environmental Processes, YICCAS, Yantai 264003, China; Center for Ocean Mega-Science, Chinese Academy of Sciences, Qingdao 266071, China; o orcid.org/0000-0002-5974-0295

Chuancheng Fu - CAS Key Laboratory of Soil Environment and Pollution Remediation, Institute of Soil Science, Chinese Academy of Sciences (CAS), Nanjing 210008, China

Lin Zeng - School of Resources and Environmental Engineering, Ludong University, Yantai 264025, China

Qian Zhou - Key Laboratory of Microbial Technology for

Industrial Pollution Control of Zhejiang Province, College of Environment, Zhejiang University of Technology, Hangzhou 310014, China

Haibo Zhang - Key Laboratory of Soil Contamination Bioremediation of Zhejiang Province, School of Environmental \& Resource Sciences, Zhejiang Agriculture and Forestry University, Hangzhou 311300, China

Chen Tu - CAS Key Laboratory of Coastal Environmental Processes and Ecological Remediation, Yantai Institute of Coastal Zone Research (YIC), Chinese Academy of Sciences (CAS); Shandong Key Laboratory of Coastal Environmental Processes, YICCAS, Yantai 264003, China; Center for Ocean Mega-Science, Chinese Academy of Sciences, Qingdao 266071, China

Lianzhen Li - CAS Key Laboratory of Coastal Environmental Processes and Ecological Remediation, Yantai Institute of Coastal Zone Research (YIC), Chinese Academy of Sciences (CAS); Shandong Key Laboratory of Coastal Environmental Processes, YICCAS, Yantai 264003, China; Center for Ocean Mega-Science, Chinese Academy of Sciences, Qingdao 266071, China

Complete contact information is available at: https://pubs.acs.org/10.1021/acs.est.1c00636

\section{Author Contributions}

${ }^{\nabla}$ Y.L. and C.F. contributed equally to this work.

\section{Notes}

The authors declare no competing financial interest.

\section{ACKNOWLEDGMENTS}

This research was supported by the National Natural Science Foundation of China (41701263, 42007022, 41991330, and 41807418). We thank Professor Bo Li at Fudan University and Professor Guangxuan Han at Yantai Institute of Coastal Zone Research, CAS for their assistance in field sampling.

\section{REFERENCES}

(1) Duarte, C. M.; Losada, I. J.; Hendriks, I. E.; Mazarrasa, I.; Marbà, $\mathrm{N}$. The role of coastal plant communities for climate change mitigation and adaptation. Nat. Clim. Change 2013, 3, 961-968.

(2) Rogers, K.; Kelleway, J. J.; Saintilan, N.; Megonigal, J. P.; Adams, J. B.; Holmquist, J. R.; Lu, M.; Schilebeers, L.; Zawadzki, A.; Mazumder, D.; Woodroffe, C. D. Wetland carbon storage controlled by millennial-scale variation in relative sea-level rise. Nature 2019, 567, 91-95.

(3) Spivak, A. C.; Sanderman, J.; Bowen, J. L.; Canuel, E. A.; Hopkinson, C. S. Global-change controls on soil-carbon accumulation and loss in coastal vegetated ecosystems. Nat. Geosci. 2019, 12, 685692.

(4) de Broek, M. V.; Vandendriessche, C.; Poppelmonde, D.; Merckx, R.; Temmerman, S.; Govers, G. Long-term organic carbon sequestration in tidal marsh sediments is dominated by old-aged allochthonous inputs in a macrotidal estuary. Global Change Biol. 2018, 24, 2498-2512. 
(5) Oreska, M. P.; Wilkinson, G. M.; Mcglathery, K. J.; Bost, M.; Mckee, B. A. Non-seagrass carbon contributions to seagrass sediment blue carbon. Limnol. Oceanogr. 2018, 63, S3-S18.

(6) Röhr, M. E.; Holmer, M.; Baum, J. K.; Björk, M.; Boyer, K.; Chin, D.; Chalifour, L.; Cimon, S.; Cusson, M.; Dahl, M.; Deyanova, D.; Duffy, J. E.; Eklöf, J. S.; Geyer, J. K.; Griffin, J. N.; Gullström, M.; Hereu, C. M.; Hori, M.; Hovel, K. A.; Hughes, A. R.; Jorgensen, P.; Kiriakopolos, S.; Moksnes, P. O.; Nakaoka, M.; O’Connor, M. I.; Peterson, B.; Reiss, K.; Reynolds, P. L.; Rossi, F.; Ruesink, J.; Santos, R.; Stachowicz, J. J.; Tomas, F.; Lee, K. S.; Unsworth, R. K. F.; Boström, C. Blue carbon storage capacity of temperate eelgrass (Zostera marina) meadows. Global Biogeochem. Cy. 2018, 32, 14571475.

(7) von Lützow, M.; Kögel-Knabner, I.; Ekschmitt, K.; Matzner, E.; Guggenberger, G.; Marschner, B.; Flessa, H. Stabilization of organic matter in temperate soils: mechanisms and their relevance under different soil conditions-a review. Eur. J. Soil Sci. 2006, 57, 426-445.

(8) Arias-Ortiz, A.; Serrano, O.; Masqué, P.; Lavery, P. S.; Mueller, U.; Kendrick, G. A.; Rozaimi, M.; Esteban, A.; Fourqurean, J. W.; Marbà, N.; Mateo, M. A.; Murray, K.; Rule, M. J.; Duarte, C. M. A marine heatwave drives massive losses from the world's largest seagrass carbon stocks. Nat. Clim. Change 2018, 8, 338-344.

(9) Macreadie, P. I.; Anton, A.; Raven, J. A.; Beaumont, N.; Connolly, R. M.; Friess, D. A.; Kelleway, J. J.; Kennedy, H.; Kuwae, T.; Lavery, P. S.; Lovelock, C. E.; Smale, D. A.; Apostolaki, E. T.; Atwood, T. B.; Baldock, J.; Bianchi, T. S.; Chmura, G. L.; Eyre, B. D.; Fourqurean, J. W.; Hall-Spencer, J. M.; Huxham, M.; Hendriks, I. E.; Krause-Jensen, D.; Laffoley, D.; Luisetti, T.; Marbà, N.; Masque, P.; McGlathery, K. J.; Megonigal, J. P.; Murdiyarso, D.; Russell, B. D.; Santos, R.; Serrano, O.; Silliman, B. R.; Watanabe, K.; Duarte, C. M. The future of Blue Carbon science. Nat. Commun. 2019, 10, 5145.

(10) Brodowski, S.; Amelung, W.; Haumaier, L.; Zech, W. Black carbon contribution to stable humus in German arable soils. Geoderma 2007, 139, 220-228.

(11) Jaffé, R.; Ding, Y.; Niggemann, J.; Vähätalo, A. V.; Stubbins, A.; Spencer, R. G. M.; Campbell, J.; Dittmar, T. Global charcoal mobilization from soils via dissolution and riverine transport to the oceans. Science 2013, 340, 345-347.

(12) Han, L.; Sun, K.; Jin, J.; Xing, B. Some concepts of soil organic carbon characteristics and mineral interaction from a review of literature. Soil Biol. Biochem. 2016, 94, 107-121.

(13) Rodionov, A.; Amelung, W.; Peinemann, N.; Haumaier, L.; Zhang, X.; Kleber, M.; Glaser, B.; Urusevskaya, I.; Zech, W. Black carbon in grassland ecosystems of the world. Global Biogeochem. Cy. 2010, 24, GB3013.

(14) Schmidt, M.; Skjemstad, J.; Gehrt, E.; Kögel-Knabner, I. Charred organic carbon in German chernozemic soils. Eur. J. Soil Sci. 1999, 50, 351-365.

(15) Gao, C.; Knorr, K.; Yu, Z.; He, J.; Zhang, S.; Lu, X.; Wang, G. Black carbon deposition and storage in peat soils of the Changbai Mountain. China. Geoderma 2016, 273, 98-105.

(16) Leifeld, J.; Alewell, C.; Bader, C.; Krüger, J. P.; Mueller, C. W.; Sommer, M.; Steffens, M.; Szidat, S. Pyrogenic carbon contributes substantially to carbon storage in intact and degraded northern peatlands. Land Degrad. Dev. 2018, 29, 2082-2091.

(17) Ponomarenko, E.; Anderson, D. Importance of charred organic matter in Black Chernozem soils of Saskatchewan. Can. J. Soil Sci. 2001, 81, 285-297.

(18) Gustafsson, Ö.; Gschwend, P. M. The flux of black carbon to surface sediments on the New England continental shelf. Geochim. Cosmochim. Ac. 1998, 62, 465-472.

(19) Middelburg, J.; Nieuwenhuize, J.; Can-Breuge, P. Black carbon in marine sediments. Mar. Chem. 1999, 65, 245-252.

(20) Wang, X.; Xu, C.; Druffel, E. R.; Xue, Y.; Qi, Y. Two black carbon pools transported by the Changjiang and Huanghe Rivers in China. Global Biogeochem. Cy. 2016, 30, 1778-1790.

(21) Fang, Y.; Chen, Y.; Lin, T.; Hu, L.; Tian, C.; Luo, Y.; Yang, X.; Li, J.; Zhang, G. Spatiotemporal trends of elemental carbon and char/ soot ratios in five sediment cores from Eastern China marginal seas: indicators of anthropogenic activities and transport patterns. Environ. Sci. Technol. 2018, 52, 9704-9712.

(22) Coppola, A. I.; Wiedemeier, D. B.; Galy, V.; Haghipour, N.; Hanke, U. M.; Nascimento, G. S.; Usman, M.; Blattmann, T. M.; Reisser, M.; Freymond, C. V.; Zhao, M.; Voss, B.; Wacker, L.; Schefuß, E.; Peucker-Ehrenbrink, B.; Abiven, S.; Schmidt, M. W. I.; Eglinton, T. I. Global-scale evidence for the refractory nature of riverine black carbon. Nat. Geosci. 2018, 11, 584-588.

(23) Chew, S. T.; Gallagher, J. B. Accounting for black carbon lowers estimates of blue carbon storage services. Sci. Rep. 2018, 8, 2553.

(24) Milliman, J. D.; Farnsworth, K. L. River discharge to the coastal ocean: a global synthesis; Cambridge University Press, 2013.

(25) Fu, C.; Li, Y.; Zeng, L.; Zhang, H.; Tu, C.; Zhou, Q.; Xiong, K.; Wu, J.; Duarte, C. M.; Christie, P.; Luo, Y. Stocks and losses of soil organic carbon from Chinese vegetated coastal habitats. Glob. Change Biol. 2021, 27, 202-214.

(26) Wang, X.; Xiao, X.; Zou, Z.; Hou, L.; Qin, Y.; Dong, J.; Doughty, R. B.; Chen, B.; Zhang, X.; Chen, Y.; Ma, J.; Zhao, B.; Li, B. Mapping coastal wetlands of China using time series Landsat images in 2018 and Google Earth Engine. ISPRS J. Photogramm. 2020, 163, 312-326.

(27) Kang, Y.; Wang, X.; Dai, M.; Feng, H.; Li, A.; Song, Q. Black carbon and polycyclic aromatic hydrocarbons (PAHs) in surface sediments of China's marginal seas. Chin. J. Oceanol. Limn. 2009, 27, 297-308.

(28) Wang, X.; Li, A. Preservation of black carbon in the shelf sediments of the East China Sea. Chin. Sci. Bull. 2007, 52, 31553161.

(29) Wang, H.; Saito, Y.; Zhang, Y.; Bi, N.; Sun, X.; Yang, Z. Recent changes of sediment flux to the western Pacific Ocean from major rivers in East and Southeast Asia. Earth-Sci. Rev. 2011, 108, 80-100.

(30) Bianchi, T. S.; Allison, M. A. Large-river delta-front estuaries as natural recorders of global environmental change. P. Natl. Acad. Sci. USA 2009, 106, 8085-8092.

(31) National Meteorological Information Center of the China Meteorological Administration, available at http://data.cma.cn.

(32) Howard, J.; Hoyt, S.; Isensee, K.; Pidgeon, E.; Telszewski, M. Coastal blue carbon: methods for assessing carbon stocks and emissions factors in mangroves, tidal salt marshes, and sea grass meadows. In Conservation International, Intergovernmental Oceanographic Commission of UNESCO. International Union for Conservation of Nature: Arlington, Virgina, USA, 2014.

(33) Lim, B.; Cachier, H. Determination of black carbon by chemical oxidation and thermal treatment in recent marine and lake sediments and Cretaceous-Tertiary clays. Chem. Geol. 1996, 131, 143-154.

(34) Mitra, S.; Zimmerman, A. R.; Hunsinger, G. B.; Willard, D.; Dunn, J. C. A Holocene record of climate-driven shifts in coastal carbon sequestration. Geophys. Res. Lett. 2009, 36, L05704.

(35) Sun, X.; Peng, P.; Song, J.; Zhang, G.; Hu, J. Sedimentary record of black carbon in the Pearl River estuary and adjacent northern South China Sea. Appl. Geochem. 2008, 23, 3464-3472.

(36) Wang, X.; Xiao, J.; Cui, L.; Ding, Z. Holocene changes in fire frequency in the Daihai Lake region (north-central China): indications and implications for an important role of human activity. Quat. Sci. Rev. 2013, 59, 18-29.

(37) Pei, W.; Wan, S.; Clift, P. D.; Dong, J.; Liu, X.; Lu, J.; Tan, Y.; Shi, X.; Li, A. Human impact overwhelms long-term climate control of fire in the Yangtze River Basin since 3.0 ka BP. Quat. Sci. Rev. 2020, 230, No. 106165.

(38) Stock, B. C.; Semmens, B. X. MixSIAR GUI user manual: version 1.0. Available from http://conserver.iugo-cafe.org/user/brice. semmens/MixSIAR . 2016.

(39) Andersson, A.; Deng, J.; Du, K.; Zheng, M.; Yan, C.; Skold, M.; Gustafsson, Ö. Regionally-varying combustion sources of the January 2013 severe haze events over Eastern China. Environ. Sci. Technol. 2015, 49, 2038-2043.

(40) Sanchez-Cabeza, J. A.; Ruiz-Fernández, A. C. ${ }^{210} \mathrm{~Pb}$ sediment radiochronology: an integrated formulation and classification of dating models. Geochim. Cosmochim. Acta 2012, 82, 183-200. 
(41) Li, Y.; Zhang, H.; Fu, C.; Tu, C.; Luo, Y.; Christie, P. A red clay layer in soils of the Yellow River Delta: Occurrence, properties and implications for elemental budgets and biogeochemical cycles. Catena 2019, 172, 469-479.

(42) Cusack, D. F.; Chadwick, O. A.; Hockaday, W. C.; Vitousek, P. M. Mineralogical controls on soil black carbon preservation. Global Biogeochem. Cy. 2012, 26, No. GB2019.

(43) Osland, M. J.; Gabler, C. A.; Grace, J. B.; Day, R. H.; McCoy, M. L.; McLeod, J. L.; From, A. S.; Enwright, N. M.; Feher, L. C.; Stagg, C. L.; Hartley, S. B. Climate and plant controls on soil organic matter in coastal wetlands. Global Change Biol. 2018, 24, 5361-5379.

(44) Sanders, C. J.; Maher, D. T.; Tait, D. R.; Williams, D.; Holloway, C.; Sippo, J. Z.; Santos, I. R. Are global mangrove carbon stocks driven by rainfall? J. Geophys. Res-Biogeo. 2016, 121, 26002609.

(45) Song, J. Z.; Peng, P. A.; Huang, W. L. Black carbon and kerogen in soils and sediments. 1. Quantification and characterization. Environ. Sci. Technol. 2002, 36, 3960-3967.

(46) Abiven, S.; Hengartner, P.; Schneider, M. P.; Singh, N.; Schmidt, M. Pyrogenic carbon soluble fraction is larger and more aromatic in aged charcoal than in fresh charcoal. Soil Biol. Biochem. 2011, 43, 1615-1617.

(47) Li, Y.; Fu, C.; Zeng, L.; Zhou, Q.; Zhang, H.; Tu, C.; Li, L.; Luo, Y. Changes in organic carbon fractions and sources in deltaic top-and subsoil layers: autochthonous and allochthonous inputs. Eur. J. Soil Sci. 2021, 131090.

(48) Rumpel, C.; Leifeld, J.; Santin, C.; Doerr, S. In Movement of biochar in the environment. Biochar for environmental management: science, technology and implementation; Lehmann, J.; Joseph, S. (eds). Routledge: Taylor \& Francis Group 2015, 283-299.

(49) Wang, R.; Tao, S.; Wang, W.; Liu, J.; Shen, H.; Shen, G.; Wang, B.; Liu, X.; Wei, L.; Huang, Y.; Zhang, Y.; Lu, Y.; Chen, H.; Chen, Y.; Wang, C.; Zhu, D.; Wang, X.; Li, B.; Liu, W.; Ma, J. Black carbon emissions in China from 1949 to 2050. Environ. Sci. Technol. 2012, 46, $7595-7603$.

(50) Chen, B.; Andersson, A.; Lee, M.; Kirillova, E. N.; Xiao, Q.; Krusa, M.; Shi, M.; Hu, K.; Lu, Z.; Streets, D. G.; Du, K.; Gustafsson, Ö. Source forensics of black carbon aerosols from China. Environ. Sci. Technol. 2013, 47, 9102-9108.

(51) Lohmann, R.; Bollinger, K.; Cantwell, M.; Feichter, J.; FischerBruns, I.; Zabel, M. Fluxes of soot black carbon to South Atlantic sediments. Global Biogeochem. Cy. 2009, 23, GB1015.

(52) Ramachandran, S.; Rupakheti, M.; Lawrence, M. G. Black carbon dominates the aerosol absorption over the Indo-Gangetic Plain and the Himalayan foothills. Environ. Int. 2020, 142, No. 105814.

(53) Xue, Y.; Zou, L.; Ge, T.; Wang, X. Mobilization and export of millennial-aged organic carbon by the Yellow River. Limnol. Oceanogr. 2017, 62, S95-S111.

(54) Galy, V.; Francelanord, C.; Beyssac, O.; Faure, P.; Kudrass, H. R.; Palhol, F. Efficient organic carbon burial in the Bengal fan sustained by the Himalayan erosional system. Nature 2007, 450, 407410.

(55) Shields, M. R.; Bianchi, T. S.; Mohrig, D.; Hutchings, J. A.; Kenney, W. F.; Kolker, A. S.; Curtis, J. H. Carbon storage in the Mississippi River delta enhanced by environmental engineering. Nat. Geosci. 2017, 10, 846-851.

(56) Qu, Y.; Jevrejeva, S.; Jackson, L. P.; Moore, J. C. Coastal Sea level rise around the China Seas. Global Planet. Change 2019, 172, 454-463.

(57) Besset, M.; Anthony, E. J.; Bouchette, F. Multi-decadal variations in delta shorelines and their relationship to river sediment supply: An assessment and review. Earth-Sci. Rev. 2019, 193, 199219.

(58) Sun, Z.; Sun, W.; Tong, C.; Zeng, C.; Yu, X.; Mou, X. China's coastal wetlands: Conservation history, implementation efforts, existing issues and strategies for future improvement. Environ. Int. 2015, 79, 25-41.
(59) Gu, J.; Luo, M.; Zhang, X.; Christakos, G.; Agusti, S.; Duarte, C. M.; Wu, J. Losses of salt marsh in China: trends, threats and management. Estuar. Coast. Shelf S. 2018, 214, 98-109. 